\title{
HTM5 Allele
}

National Cancer Institute

\section{Source}

National Cancer Institute. hTM5 Allele. NCI Thesaurus. Code C129378.

Human hT M5 allele is a variant form of the human TPM3 gene located 1q21.2 and is approximately $39 \mathrm{~kb}$ in length. This allele, which encodes tropomyosin alpha-3 chain low isoform 2, is involved in maintenance of the cytoskeleton. 